Arq. Bras. Med. Vet. Zootec., v.68, n.3, p.641-650, 2016

\title{
Effects of timolol maleate, levobunolol and apraclonidine on intraocular pressure, pupil size, blood pressure and heart rate in beagles
}

\author{
[Efeitos do maleato de timolol, do levobunolol e da apraclonidina sobre a pressão intraocular, o diâmetro \\ pupilar, a pressão sanguínea e a frequência cardíaca, em cães da raça Beagle] \\ I.R.M. Padua ${ }^{1}$, A.P. Ribeiro ${ }^{2}$, P.P.M. Padua ${ }^{3}$, P.J. Guimarães ${ }^{1}$, M.L. Silva ${ }^{1}$, D.Y.T. Piso ${ }^{5}$, \\ B. Martins ${ }^{4}$, M. Aldrovani ${ }^{1}$, L.M.S. Semolin ${ }^{1}$, A.A. Camacho ${ }^{1}$, J.L. Laus ${ }^{1 *}$ \\ ${ }^{1}$ Universidade Estadual Paulista (UNESP) - Jaboticabal, SP \\ ${ }^{2}$ Universidade Federal do Mato Grosso - Cuiabá, MT \\ ${ }^{3}$ Fundación Universitaria Agraria de Colombia - Bogotá - Colombia \\ ${ }^{4}$ University of Florida - Gainesville, FL - USA \\ ${ }^{5}$ Universidad Cooperativa de Colombia, Ibagué - Colombia
}

\begin{abstract}
The aim of this study was to evaluate changes in intraocular pressure (IOP), pupil size (PS), blood pressure (BP), heart rate (HR), and ECG variables (Pms wave PmV, PR interval, QRS complex, RMV wave and QT intervals) over time during the instillation of $0.5 \%$ timolol, $0.5 \%$ levobunolol and $0.5 \%$ apraclonidine in clinically normal dogs. Ten adult beagles were used. Baseline values were measured at 8a.m., 2p.m. and 8p.m., for three consecutive days. A waiting period of 10 days between the administrations of each drug was established. For 15 consecutive days, the drug being tested was instilled in one eye of each dog twice a day (7a.m. and 7p.m.). The parameters were evaluated at the aforementioned times on days 3, 6, 9, 12 and 15 . Data were statistically compared using the Bonferroni test and one-way repeated measures analysis of variance $(\mathrm{P}<0.05)$. The Pearson test was used to evaluate any correlation between QT interval, HR and BP. The tested drugs did not find a decrease in IOP. A significant decreased in PS was observed in almost all dogs following levobunolol administration, relative to the control eye. A significant decrease in HR was observed on day 3 following levobunolol treatment, while apraclonidine induced an increase on day 15 . Blood pressure was reduced in all measurement time points following apraclonidine treatment. A negative correlation between QT interval and HR was only observed in dogs treated with timolol. In conclusion, levobunolol was the only drug that induced significant alterations in PS. Apraclonidine was the only drug that induced systemic hypotension. Timolol was the only drug to that induced a negative correlation between QT and HR.
\end{abstract}

Keywords: dog, timolol maleate, levobunolol, apraclonidine, intraocular pressure, pupil size, heart rate, blood pressure

\section{RESUMO}

O objetivo deste estudo foi avaliar as mudanças na pressão intraocular (PIO), no diâmetro pupilar (DP), na pressão sanguínea (PS), na frequência cardíaca (FC) e nas variáveis eletrocardiográficas (onda Pms, PmV, intervalo $P R$, complexo QRS, onda $R m V$ e intervalo $Q T$ ), ao longo do tempo da instilação do timolol 0,5\%, do levobunolol 0,5\% e da apraclonidina 0,5\% em cães clinicamente normais. Dez Beagles adultos compuseram o estudo. Valores basais foram mensurados às oito,, 14 e 20 horas, durante três dias consecutivos. Foi instituído um período de espera de 10 dias entre a administração de cada fármaco. Durante 15 dias consecutivos, um olho de cada animal recebeu uma gota de cada um deles, a intervalos de 12 horas (às sete e às 19 horas). Os parâmetros foram avaliados nos momentos acima referidos, nos dias três, seis, nove, 12 e 15. Os dados foram comparados estatisticamente empregando-se o teste de Bonferroni após análise de variância para medidas repetidas $(P<0,05)$. Teste de Pearson foi utilizado

Recebido em 29 de outubro de 2014

Aceito em 3 de dezembro de 2015

*Autor para correspondência (corresponding author)

E-mail: jllaus@fcav.unesp.br 
para correlação entre o intervalo QT com a FC e a PS. Não se encontrou diminuição da PIO. Observouse redução significativa do DP na quase totalidade dos animais que receberam levobunol, relativamente ao olho controle. Diminuição significativa da FC foi vista ao terceiro dia após a administração do levobunolol, enquanto apraclonidina induziu aumento no $15^{\circ}$ dia. A pressão arterial foi reduzida em todos os momentos com a apraclonidina. Observou-se correlação negativa entre o intervalo QT e a FC apenas nos indivíduos tratados com o timolol. Em conclusão, levobunolol foi o único fármaco que induziu alterações significativas no DP. A apraclonidina foi o único fármaco que induziu hipotensão sistêmica significativa. O timolol foi o único a ensejar correlação negativa entre o intervalo QT e a FC.

Palavras-chave: cão, maleato de timolol, levobunolol, apraclonidina, pressão intraocular, diâmetro pupilar, frequência cardíaca, pressão sanguínea

\section{INTRODUCTION}

Some topical and systemic drugs decreasing aqueous humor production or increase its drainage (Gelatt, 2007).

Topical prostaglandin analogues and carbonic anhydrase inhibitors are the most efficient drugs for controlling glaucoma in humans and dogs (Willis, 2004). Nevertheless, their action is potentialized when associated with other hypotensive medications, such as $\beta$-blocking agents (Plumer et al., 2006; Kaback et al., 2008). $\beta$-blockers reduce intraocular pressure (IOP) by blocking $\beta$-receptors at the ciliary body, hence decreasing the formation of aqueous humor (Willis, 2004). Timolol and levobunolol are nonspecific $\beta$-blocking agents (i.e., they block both $\beta 1$ and $\beta 2$ receptors). Besides blocking $\beta$ receptors, timolol induces miosis by stimulating the $\alpha$-adrenergic receptors of the iris sphincter. Its maximum action occurs within 2 to 6 hours in dogs and maximum IOP reduction (27\%) is observed on day 7 of treatment (Wilkie and Latimer, 1991; Ribeiro et al., 2007). Common side effects reported in dogs are a significant decrease in heart rate and blood pressure, induced by blockage of systemic $\beta$-receptors (Maehara et al., 2004; Nieminen et al., 2005). Arrhythmia and heart blockage are associated with $\beta 1$ blockage, while bronchospasm and respiratory obstruction are associated with $\beta 2$ blockade effects (Willis, 2004).

Levobunolol has the potential to induce an IOP reduction of up to $3.2 \mathrm{mmHg}$ in humans with normal pressure glaucoma and up to $7.0 \mathrm{mmHg}$ in those with primary open angle glaucoma (Akafo et al., 1995; Inoue et al., 2005). However, a decrease in heart rate has been associated with the use of levobunolol and this agent has been shown to cause more intense bradycardia than timolol in cats and humans (Derrick et al., 1992; Ribeiro et al., 2007)

Apraclonidine is a selective $\alpha-2$ agonist acting on the ciliary body nonpigmented epithelial cells. The drug suppresses the activity of adenylate cyclase by inhibiting the conversion of ATP to cAMP, hence decreasing aqueous humor production (Willis, 2004). A single topical administration of $0.5 \%$ apraclonidine in a healthy canine eye reduced the IOP by $16 \%, 8$ hours after treatment. Blepharospasm and pale conjunctiva are the most common side effects observed in dogs (Miller and Rhaesa, 1996).

\section{MATERIALS AND METHODS}

The project was approved by the Committee of Ethics and Animal Welfare of the College of Agricultural and Veterinary Sciences (FCAV) of São Paulo State University (UNESP), Jaboticabal, SP, Brazil, under protocol no. 007105-06. The study followed the guidelines of the Association for Research in Vision and Ophthalmology - ARVO (National Institutes of Health Publications No 85-23: Revised 1985).

Ten adult male beagles weighing between 9.5 and $13 \mathrm{~kg}$ were used. All the dogs belonged to the Laboratory for Nutrition and Nutritional Diseases Research of FCAV-UNESP. All the dogs were submitted to routine clinical and ophthalmic evaluation prior to the study. Only healthy beagles were selected for the research.

The same investigator, who was blinded regarding the treatment administered to the dogs, performed all the procedures. Following the administration of topical anesthetics (Proximetacaína, Anestalcon, Alcon, São Paulo, Brazil), baseline values for IOP (TonoPen XL, 
Reichert ${ }^{\circledR}$ ) and pupil size (PS) were obtained. Mean IOPs were obtained using values that achieved less than 5\% standard deviation between three measurements. The final IOP value was the mean of these three measurements. PS was measured under uniform ambient illumination on the horizontal axis in the center of the pupil, using a Jameson caliper.

Systolic arterial blood pressure (BP) was measured by noninvasive vascular Doppler (Ultrasonic Doppler Flow Detector Model 812). Five measurements were obtained and the highest and lowest values were discarded, in order to provide a more accurate mean value (Mucha and Camacho, 2007).

Heart rate (HR) was obtained by a computerized electrocardiographic device (ECG-PC, version $2.07^{\circledR}$, TEB, São Paulo, Brazil) based on limbal leads (I, II, III, aVR, aVL and aVF) and precordial leads (rV2, V2, V4 and V10). The electrocardiograms (ECGs) were evaluated on bipolar derivation II (DII), at $50 \mathrm{~mm} / \mathrm{sec}$, calibrated to $1 \mathrm{mV} / \mathrm{cm}$. The parameters evaluated were heart rhythm, heart rate, $\mathrm{P}$ wave duration (Pms) and amplitude (PmV), PR interval duration, QRS complex duration, R-wave amplitude, QT interval duration, T-wave polarity and presence or absence of ST segment denivelation (Tilley, 1992).

During the study, IOP, PS, HR and BP measurements were performed at three different time points (8a.m., 2p.m. and 8p.m.). To familiarize the dogs with the investigators and the procedures, they were trained eight days prior to the onset of the study to avoid inaccurate readings. Baseline values were measured at 8a.m., 2p.m. and 8p.m. for three consecutive days.

For the first phase of the study, during the next consecutive 15 days, the right (OD) or left eye (OS) was randomly assigned for treatment with $0.5 \%$ timolol maleate (Maleato de Timolol $0.5 \%$,
Guarulhos, Brazil) (administered at 7a.m. and 7 p.m.), while the contra-lateral eye was administered $0.9 \%$ sterile saline (administered at 7a.m. and 7p.m.). All the parameters were recorded at the same times aforementioned, on days $3,6,9,12$ and 15 .

After a wash-out period of 10 days, the second phase of the study was initiated. The same protocol was used, with $0.5 \%$ levobunolol (Betagan $^{\circledR}$, Allergan, Guarulhos, Brazil) as the treatment drug. After a second wash-out period of 10 days, the third phase was initiated and $0.5 \%$ apraclonidine (Iopidine $0.5 \%$, Alcon, SP, Brazil) was used as the treatment drug.

All data were analyzed by statistics software (Systat Software inc®, San Jose, California, USA). Overall changes were compared by one-way repeated measure analysis of variance with Kolmogorov-Smirnov test for normal distribution. A Bonferroni correction was performed as a post-hoc test. The Pearson test was used to evaluate any correlations between QT interval, HR and BP. For all analyses, the results were considered significant when $\mathrm{P}<0.05$.

\section{RESULTS}

For intraocular pressure, the mean \pm SEM of the baseline values of OD and OS was $12.02 \pm 0.3674 \mathrm{mmHg}$. Intraocular pressure parameters values are summarized in Figure 1.

For pupil size, the mean \pm SEM of the baseline of OD and OS was $7.728 \pm 0.2378 \mathrm{~mm}$. Pupil size parameters values are summarized in Figure 2.

For blood pressure, the mean \pm SEM of the baseline values was $150.3 \pm 2.402 \mathrm{mmHg}$. Blood pressure parameter values are summarized in Figure 3.

Heart rate base values were $98.41 \pm 2.592 \mathrm{bpm}$. Heart rate parameter values are summarized in Figure 4. 

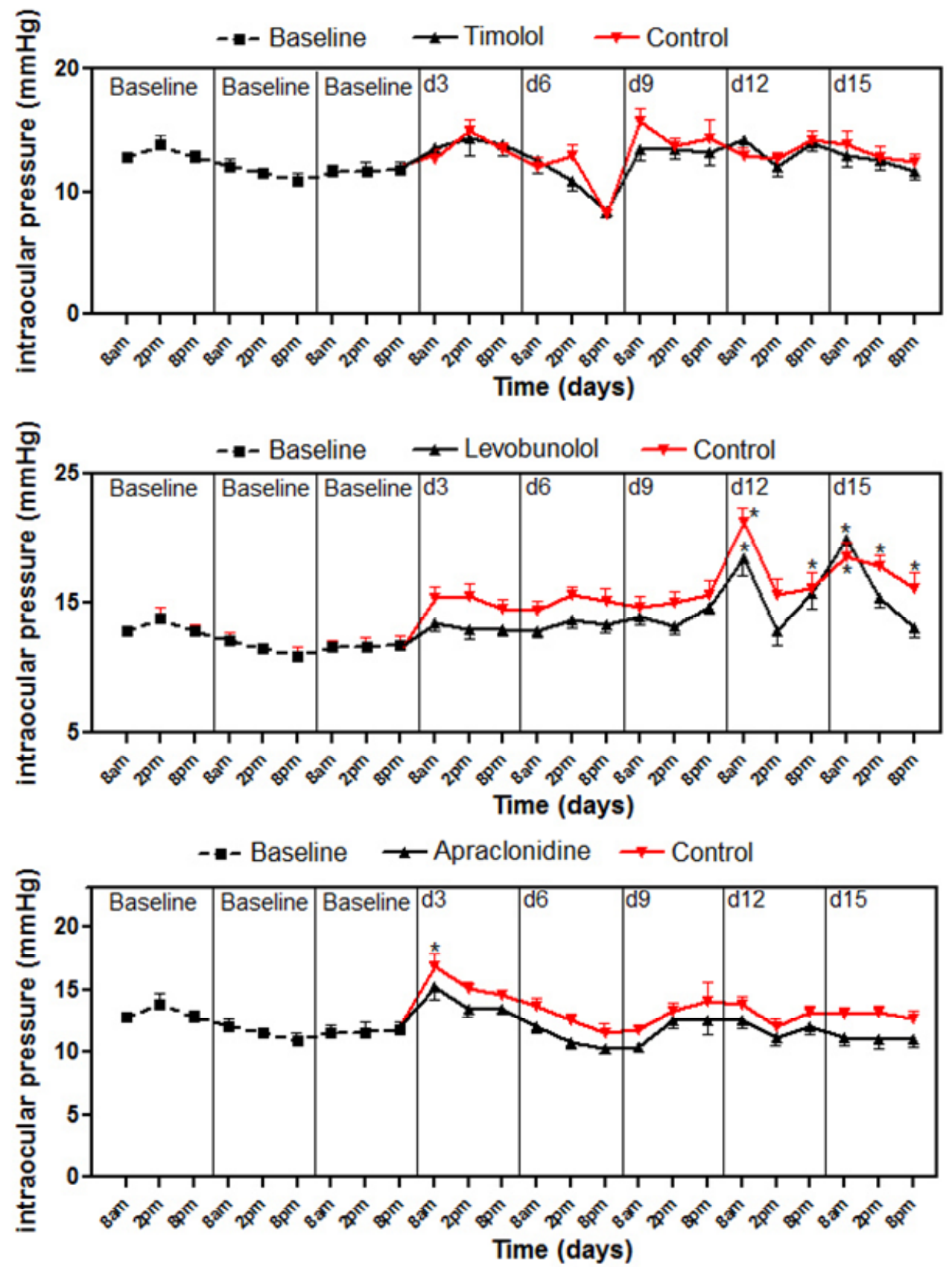

Figure. 1. Mean IOP values following 0.5\% timolol, $0.5 \%$ levobunolol and $0.5 \%$ apraclonidine administration on days 3, 6, 9, 12 and 15, at 8a.m., 2p.m. and 8p.m., in healthy male adult beagles. * Significant $(\mathrm{P}<0.05)$ compared with baseline values. 

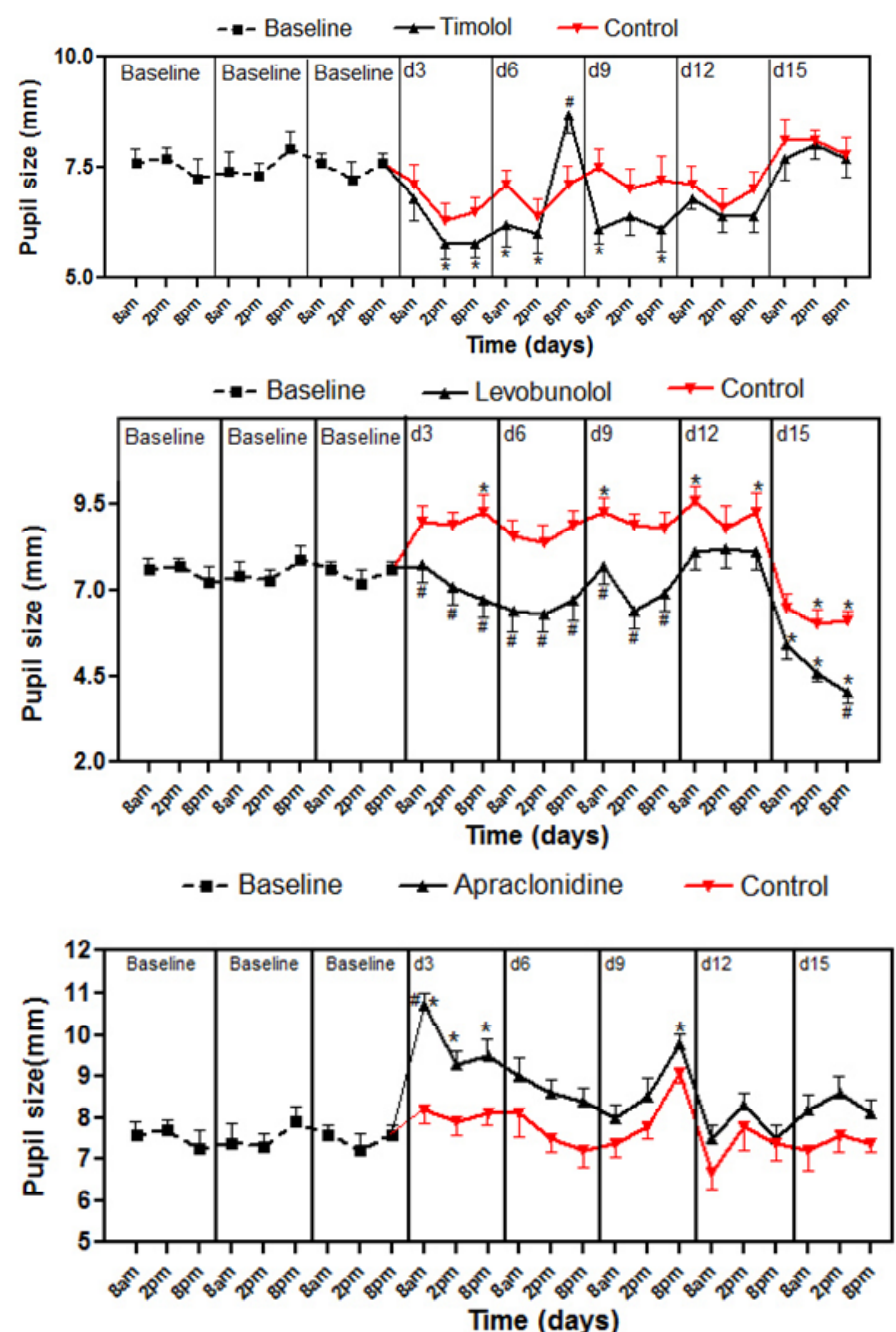

Figure 2. Mean pupil size values following $0.5 \%$ timolol, $0.5 \%$ levobunolol and $0.5 \%$ apraclonidine administration on days 3, 6, 9, 12 and 15, at 8a.m., 2p.m. and 8p.m., in healthy male adult beagles. *Significant $(\mathrm{P}<0.05)$ when compared with baseline values. ${ }^{\#}$ significant $(\mathrm{P}<0.05)$ comparing treated eye to control eye.

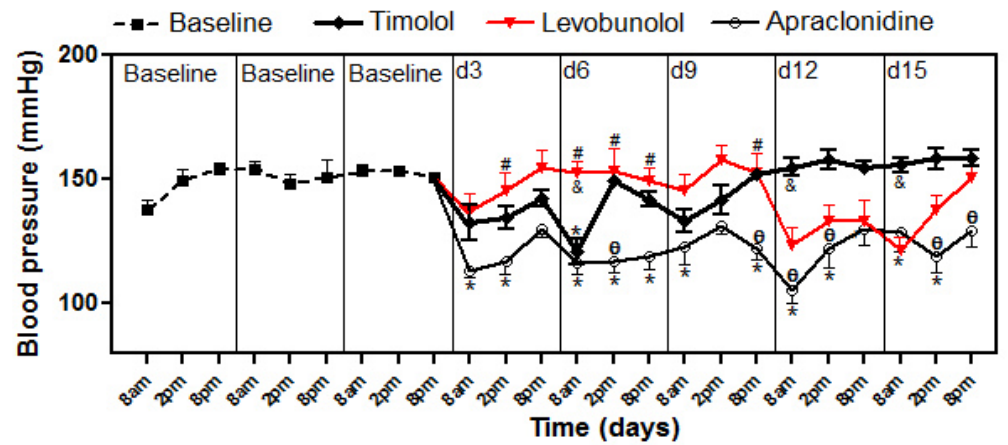

Figure 3. Mean blood pressure values following administration of $0.5 \%$ timolol, $0.5 \%$ levobunolol and $0.5 \%$ apraclonidine on days 3, 6, 9, 12 and 15 , at 8 a.m., 2p.m. and 8p.m., in healthy male adult beagles. *Significant $(\mathrm{P}<0.05)$ when compared with baseline values; ${ }^{\theta}$ significant $(\mathrm{P}<0.05)$ comparing timolol with apraclonidine; ${ }^{\#}$ significant $(\mathrm{P}<0.05)$ comparing levobunolol with apraclonidine; ${ }^{*}$ significant $(\mathrm{P}<0.05)$ comparing timolol with levobunolol. 


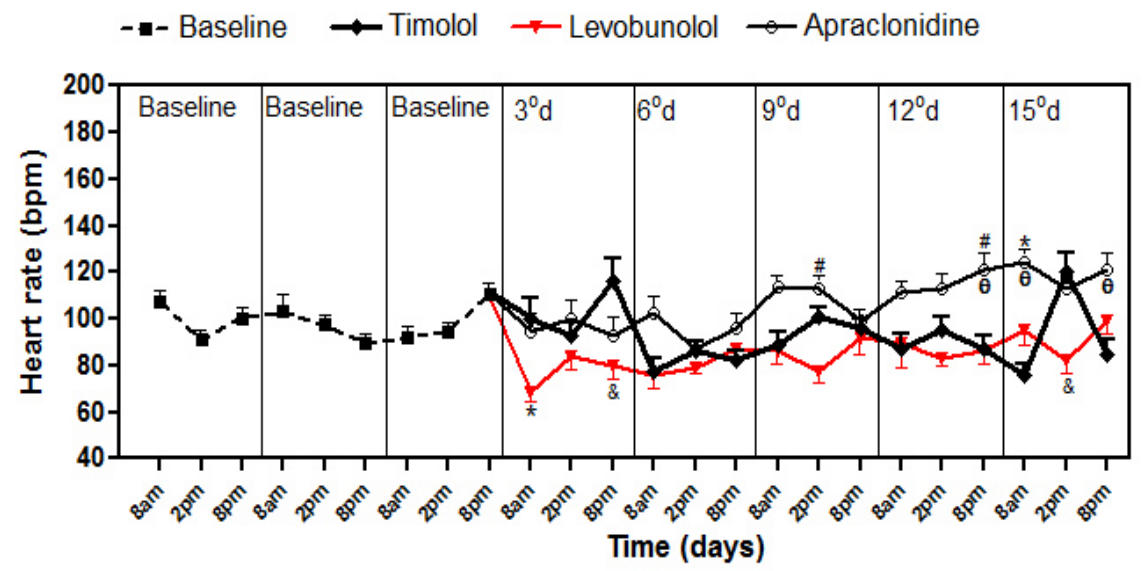

Figure 4. Mean heart rate values following administration of $0.5 \%$ timolol, $0.5 \%$ levobunolol and $0.5 \%$ apraclonidine on days 3, 6, 9, 12 and 15, at 8a.m., 2p.m. and 8p.m., in healthy male adult beagles. ${ }^{*}$ Significant $(\mathrm{P}<0.05)$ when compared with baseline values; ${ }^{\theta}$ significant $(\mathrm{P}<0.05)$ comparing timolol with apraclonidine; " significant $(\mathrm{P}<0.05)$ comparing levobunolol with apraclonidine; ${ }^{\&}$ significant $(\mathrm{P}<0.05)$ comparing timolol with levobunolol.

The ECG parameter values (mean \pm SEM) for Pms, PmV, PR interval, QRS complex, R wave amplitude and QT interval are summarized in Table 1.
A negative correlation was observed between the QT interval and HR only in dogs treated with timolol $\left(\mathrm{P}=0.023 ; \mathrm{r}^{2}=0.76\right)$. These results are summarized in Table 2.

Table 1. Mean value and standard error of mean of electrocardiographic parameters (Pms, PmV, PR, QRS, RmV and QT) following 0.5\% timolol, $0.5 \%$ levobunolol and $0.5 \%$ apraclonidine administration on days 3, 6, 9, 12 and 15, at 8a.m, 2p.m and 8p.m, in healthy male adult beagles

\begin{tabular}{|c|c|c|c|c|c|c|}
\hline Parameter & Baseline & day 3 & day 6 & day 9 & day 12 & day 15 \\
\hline \multicolumn{7}{|l|}{ Timolol } \\
\hline Pms & $42.56 \pm 0.44$ & $41.80 \pm 0.35$ & $42.30 \pm 0.15$ & $42.70 \pm 0.68$ & $41.70 \pm 0.44$ & $42.00 \pm 0.21$ \\
\hline $\mathrm{PmV}$ & $0.21 \pm 0.01$ & $0.18 \pm 0.01 \mathrm{~b}$ & $0.20 \pm 0.01$ & $0.19 \pm 0.06$ & $0.19 \pm 0.013 \mathrm{a}$ & $0.19 \pm 0.01$ \\
\hline PR & $108.5 \pm 5.37$ & $111.6 \pm 5.13$ & $116.4 \pm 5.45 b$ & $111.3 \pm 4.41$ & $109.7 \pm 4.99$ & $110.8 \pm 5.01$ \\
\hline QRS & $47.01 \pm 0.72$ & $46.60 \pm 0.96$ & $46.37 \pm 1.20$ & $46.73 \pm 0.96$ & $47.67 \pm 0.97$ & $45.47 \pm 0.72$ \\
\hline $\mathrm{RmV}$ & $1.22 \pm 0.10$ & $1.10 \pm 0.11 \mathrm{~b}$ & $1.16 \pm 0.08$ & $1.09 \pm 0.10 \mathrm{~b}$ & $1.10 \pm 0.10 \mathrm{~b}$ & $1.13 \pm 0.11$ \\
\hline QT & $210.7 \pm 2.92$ & $208.8 \pm 2.59$ & $217.0 \pm 2.00$ & $214.8 \pm 1.59$ & $218.5 \pm 2.85 \mathrm{a}$ & $214.5 \pm 1.49$ \\
\hline \multicolumn{7}{|c|}{ Levobunolol } \\
\hline Pms & $42.56 \pm 0.44$ & $43.40 \pm 0.56$ & $42.97 \pm 0.55$ & $43.73 \pm 0.42$ & $42.63 \pm 0.51$ & $42.90 \pm 0.39$ \\
\hline $\mathrm{PmV}$ & $0.21 \pm 0.012$ & $0.22 \pm 0.03$ & $0.19 \pm 0.00$ & $0.20 \pm 0.01$ & $0.21 \pm 0.010$ & $0.21 \pm 0.01$ \\
\hline PR & $108.5 \pm 5.37$ & $120.6 \pm 6.05 b$ & $118.3 \pm 5.88 \mathrm{a}$ & $115.5 \pm 5.164$ & $117.8 \pm 5.62 \mathrm{a}$ & $116.8 \pm 5.02$ \\
\hline QRS & $47.01 \pm 0.72$ & $46.93 \pm 0.92$ & $46.67 \pm 0.73$ & $45.73 \pm 1.231$ & $46.33 \pm 0.56$ & $42.70 \pm 0.60 c$ \\
\hline $\mathrm{RmV}$ & $1.22 \pm 0.102$ & $1.05 \pm 0.10 \mathrm{c}$ & $1.12 \pm 0.10$ & $1.10 \pm 0.10$ & $1.15 \pm 0.10$ & $1.10 \pm 0.08 \mathrm{a}$ \\
\hline QT & $210.7 \pm 2.92$ & $219.9 \pm 2.53 \mathrm{a}$ & $216.5 \pm 3.28$ & $222.3 \pm 3.41 b$ & $221.5 \pm 1.33 b$ & $216.9 \pm 1.86$ \\
\hline \multicolumn{7}{|c|}{ Apraclonidine } \\
\hline Pms & $42.56 \pm 0.44$ & $42.43 \pm 0.53$ & $42.33 \pm 0.46$ & $42.23 \pm 0.34$ & $42.97 \pm 0.26$ & $42.63 \pm 0.52$ \\
\hline $\mathrm{PmV}$ & $0.21 \pm 0.01$ & $0.18 \pm 0.01 \mathrm{c}$ & $0.20 \pm 0.01$ & $0.19 \pm 0.01$ & $0.20 \pm 0.01$ & $0.19 \pm 0.01 \mathrm{a}$ \\
\hline PR & $108.5 \pm 5.37$ & $106.7 \pm 4.44$ & $107.9 \pm 4.07$ & $106.6 \pm 4.90$ & $101.3 \pm 4.13 \mathrm{a}$ & $99.50 \pm 3.69 c$ \\
\hline QRS & $47.01 \pm 0.72$ & $46.20 \pm 1.08$ & $44.87 \pm 1.16$ & $45.80 \pm 0.93$ & $46.83 \pm 1.03$ & $48.33 \pm 0.75$ \\
\hline $\mathrm{RmV}$ & $1.22 \pm 0.10$ & $1.074 \pm 0.116$ & $1.15 \pm 0.10$ & $1.00 \pm 0.13 b$ & $1.19 \pm 0.10$ & $1.11 \pm 0.14$ \\
\hline QT & $210.7 \pm 2.99$ & $204.1 \pm 2.45$ & $204.5 \pm 2.08$ & $204.3 \pm 2.85$ & $198.6 \pm 2.90 \mathrm{c}$ & $195.5 \pm 2.84 \mathrm{c}$ \\
\hline
\end{tabular}

${ }^{\mathrm{a}} \mathrm{P}<0.05,{ }^{\mathrm{b}} \mathrm{P}<0.01,{ }^{\mathrm{c}} \mathrm{P}<0.001$. Significances compared to baseline values. 
Table 2. Linear regression results between the QT interval and heart rate (HR) and between the QT interval and blood pressure (BP) following $0.5 \%$ timolol, $0.5 \%$ levobunolol and $0.5 \%$ apraclonidine administration in healthy male adult beagles

\begin{tabular}{cccc} 
& Timolol & Levobunolol & Apraclonidine \\
\cline { 2 - 4 } QT interval x HR & & & \\
\hline $\mathrm{P}$ & 0.023 & 0.148 & 0.051 \\
$\mathrm{r}^{2}$ & 0.760 & 0.444 & 0.654 \\
QT interval x BP & & & 0.192 \\
\hline $\mathrm{P}$ & 0.511 & 0.555 & 0.380 \\
\hline $\mathrm{r}^{2}$ & 0.114 & 0.093 &
\end{tabular}

*the Pearson test.

\section{DISCUSSION}

Controlling IOP is mandatory for glaucoma management (Gelatt and Brooks, 1999; Choudri et al., 2000). The reasons for investigating the selected $\beta$-blockers and $\alpha-2$ agonist agents include the fact that these drugs are routinely used to control IOP, since they potentialize the effects of carbonic anhydrase inhibitors and prostaglandin analogues. Nevertheless, these drugs can cause important systemic side effects that must be considered (Wheeler and Woldemussie, 2001; Willis, 2004).

For decades, timolol has been used in the management of glaucoma in humans and animals (Plumer et al., 2006). Our results are in agreement with previous studies in which timolol alone or associated with latanoprost did not reduce IOP values in normal dogs (Gum et al., 1991; Smith et al., 2010). However, other studies have reported a reduction in IOP ranging between 16.1 and $27.1 \%$ from hours to a week after timolol administration in normal dogs. The reasons for such controversial results in studies with healthy dogs are unknown (Wilkie and Latimer, 1991; Maehara et al., 2004; Borges et al., 2007).

The efficacy of timolol has been reported in glaucomatous dogs and an IOP reduction of 3.75 and $2.21 \mathrm{mmHg}$ was observed in the affected and contralateral eyes, respectively (Plumer et al., 2006). In humans, an IOP reduction between 28 and $32 \%$ was observed after instillation of $0.5 \%$ timolol (Heijl et al., 1997). As occurs in humans, in dogs, it has been suggested that the association of two hypotensive agents will achieve better efficiency in lowering IOP (Ribeiro et al., 2008).
The fact that there are few reports available comparing the effects of levobunolol with other substances motivated this study. In cats, although no uniform changes in IOP were observed, levobunolol significantly reduced IOP ($2.91 \mathrm{mmHg}$ ) six hours after the first administration (Ribeiro et al., 2008). Similar results have been reported in dogs (Pugliese et al., 2009).

In humans with glaucoma, the effects of timolol and levobunolol on reducing IOP are similar (Miller and Rhaesa, 1996). Another study performed on healthy dogs reported a significant reduction in IOP in the first 24 hours following levobunolol administration and also reported that the effects were more evident four days after the initial therapy (Maehara et al., 2004; Pugliese et al., 2009). In this study, IOP was measured for 15 days and no decrease in IOP was observed in any measurement time point following timolol or levobunolol administration.

In healthy dogs, an IOP reduction of $16 \%$ $(3 \mathrm{mmHg})$ has been reported in dogs 8 hours after administration of $0.5 \%$ apraclonidine (Miller et al., 1996). A reduction in IOP was observed in all measurement time points in our investigation, but no statistical significance was determined.

Miosis was observed in eyes treated with timolol and levobunolol and was more evident after levobunolol instillation. Miosis was observed compared with baseline values (not significant) in some measurement time points. Similar results were observed in another study that reported a significant decrease in pupil diameter on day 2 of treatment compared with baseline values, and a non-significant decrease in PS compared with the control eye (Plumer et al., 2006). 
In this study, levobunolol caused a significant reduction in PS compared with control eyes in 10 of the 15 points of evaluation, which is in agreement with the reported in dogs and cats (Ribeiro et al., 2008; Pugliese et al., 2009). Miosis was expected, since these drugs act by either inhibiting the $\beta$-receptors or stimulating the $\alpha$-adrenergic receptors in the iris sphincter (Wilkie and Latimer, 1991). However, the reason why levobunolol induced a more pronounced miosis compared with other drugs is unknown. Apraclonidine caused mydriasis, which was observed at all evaluation points. However, the difference in PS was only significant for the $1^{\text {st }}$, $2^{\text {nd }}, 3^{\text {rd }}$ and $9^{\text {th }}$ measurement time points. In contrast to dogs, where it causes mydriasis, apraclonidine induces miosis for up to 24 hours following administration in cats, and a reduction of $46 \%$ can be observed in PS (Miller et al., 1996).

Compared with baseline values, timolol and levobunolol reduced the blood pressure in only one of the 15 measurement time points. In contrast, the blood pressure was reduced in most of the evaluations following treatment with apraclonidine, probably due to its properties as an alpha-2 adrenergic agonist.

Other researchers have observed a significant reduction in heart rate after the instillation of timolol in glaucomatous dogs (Plumer et al., 2006). The same result was reported in healthy dogs (Smith et al., 2010). In our study, no significant alteration in HR was observed following treatment with timolol. However, levobunolol significantly reduced the HR on the first day of evaluation and in other time points, similar to results observed by other authors in healthy dogs and cats (Ribeiro et al., 2008; Pugliese et al., 2009). Similar results showed a decrease in HR in 4 out of 9 dogs studied, 2 hours after treatment with apraclonidine (Miller et al., 1996). In this study, apraclonidine increased the HR in almost all the time points evaluated, as expected, due to decreased blood pressure.

A decrease in R-wave millivoltage was observed following the administration of all the drugs, but especially following timolol, which significantly decreased this parameter at three time points. A decrease in PmV was also observed in all the time points evaluated, and a significant decrease was observed in two time points following the administration of timolol and apraclonidine.

We suggest that the decrease observed in the PR interval duration following apraclonidine was a rebound effect from the increase in HR. Following timolol administration, a slight increase in the PR interval was observed only in one time point; whereas after levobunolol administration, PR interval values were higher than the reported reference values in all time points, probably due to the first-degree atrioventricular block secondary to the decrease in HR, associated with the adrenergic beta block effect of the drug.

Regarding the electrocardiographic results, the QT interval is the best parameter to demonstrate the systemic effects of the treatments, since it is inversely proportional to heart rate. Drugs that interfere with the autonomic nervous system dynamics may induce alterations in the QT interval directly or by a reduction in HR (Tilley, 1992).

The QT interval showed a tendency towards elevation following timolol administration, along with a negative correlation with HR. Following levobunolol, a significant increase in the QT interval was observed, however no correlation with HR was determined. A significant decrease was observed in the QT interval at the two last time points following apraclonidine administration; we suggest that this decrease in the QT interval was caused by the increase in HR following blood pressure decrease. Although no correlation was observed between the QT interval and $\mathrm{BP}$, the $p$ value of 0.051 , very close to the level of significance, may well indicate an eventual systemic action of the drug.

\section{CONCLUSIONS}

The antiglaucoma drugs currently used were unable to decrease IOP in normal dogs; however, they caused significant changes in pupil size, heart rate and electrocardiographic values. Levobunolol induced more alterations in PS, HR and ECG. Apraclonidine and timolol caused alterations only in HR and ECG, respectively. These results suggest that cardiovascular monitoring should be considered in patients prescribed timolol, levobunolol and apraclonidine. 


\section{SUPPORT}

The National Council of Technological and Scientific Development (CNPq, 300833/2010-5), and the São Paulo Research Foundation (FAPESP, 2011/20041-8).

\section{REFERENCES}

AKAFO, S.K.; THOMPSON, J.R.; ROSENTHAL, A.R. Cross-over trial comparing once daily levobunolol with once and twice daily timolol. Eur. J. Ophthalmol., v.5, p.172-176, 1995.

BORGES, A.G.; BRANDAO, C.V.S.; RANZANI, J.J.T.; ADALBERTO, J.C. Efeitos maleato de timolol $0.5 \%$ do cloridrato de dorzolamida $2 \%$, e da associação de ambas na pressão intra-ocular. Arq. Bras. Med. Vet. Zootec., v.59, p.660-664, 2007.

CHOUDRI, S.; WAND, M.; SHIELDS, M.B. A comparison of dorzolamide-timolol combination versus the concomitant drugs. Am. J. Ophthalmol., v.130, p.832-833, 2000

DERRICK, R.J.; ROBIN, A.L.; TIELSCH, J. et al. Once-daily versus twice-daily levobunolol $(0.5 \%)$ therapy: a crossover study. Ophthalmology, v.99, p.424-429, 1992.

GELATT, K.N.; BROOKS, D.E. The canine glaucomas. In: GELATT, K.N.; GILGER, B.C.; THOMAS, T.J. (Eds.). Veterinary ophthalmology. Philadelphia: Lippincott, Williams and Wilkins, 1999. p.701-754.

GELATT, K.N. The canine glaucoma. In. GELATT, K.N.; GILGER, B.C.; THOMAS, T.J. (Eds.). Veterinary ophthalmology. Iowa: Blackwell Publishing, 2007. p.753-811.

GUM, G.G.; LAROCCA, R.D.; GELATT, K.N. The effects of topical timolol maleate on intraocular pressure in normal beagles and beagles with inherited glaucoma. Prog. Vet. Comp. Ophthalmol., v.1, p.141-149, 1991.

HEIJL, A.; STRAHLMAN, E.; SVERRISON, T. A comparison of dorzolamide and timolol in patients with pseudoexfoliation and glaucoma or ocular hypertension. Ophthalmology, v.104, p.137-42, 1997.

INOUE, K.; EZURE, T.; WAKAKURA, M. The effect of once-daily levobunolol on intraocular pressure in normal-tension glaucoma. Jpn. J. Ophthalmol., v.49, p.56-67, 2005.
KABACK, M.; SCOPER, S.V.; ARZENO, G. et al. Intraocular pressure-lowering efficacy of brinzolamide $\quad 1 \% /$ timolol $\quad 0.5 \%$ fixed combination compared with brinzolamide $1 \%$ and timolol $0.5 \%$. Ophthalmology, v.115, p.1728-1734. 2008.

MAEHARA, S.; ONO, K.; ITO, N.; TSUZUKI, K. et al. Effects of topical nipradilol and timolol maleate on intraocular pressure, facility outflow, arterial blood pressure and pulse rate in dogs. Vet. Ophthalmol., v.7, p.147-150, 2004.

MILLER, P.E.; RHAESA, S.L. Effects of topical administration of $0,5 \%$ apraclonidine on intraocular pressure, pupil size, and heart rate in clinically normal cats. Am. J. Vet. Res., v.57, p.83-86, 1996.

MILLER, P.E.; NELSON, M.J.; RHAESA, S.L. Effects of topical administration of $0.5 \%$ apraclonidine on intraocular pressure, pupil size, and heart rate in clinically normal dogs. Am. J. Vet. Res., v.57, p.79-82, 1996.

MUCHA, C.J.; CAMACHO, A.A. Determinación de la Presión Arterial. In: BELERENIAN, G.; MUCHA, C.J.; CAMACHO, A.A.; GRAU, J.M. Afecciones cardiovasculares en pequeños animales. Buenos Aires: Intermedica, 2007. p.179-183.

NIEMINEN, T.; UUSITALO, H.; TURJANMAA, V. Association between low plasma levels of ophthalmic timolol and haemodynamics in glaucoma patients. Eur. J Clin. Pharmacol., v.6, p.369-374, 2005.

PLUMER, C.E.; MAC KAY, E.O.; GELATT, K.N. Comparison of the effects of topical administration of a fixed combination of dorzolamide-timolol to monotherapy with timolol or dorzolamide on IOP heart rate in glaucomatous beagles. Vet. Ophthalmol., v.9, p.245-249, 2006.

PUGLIESE, M.; SCARDILLO, A.; NIUTTA, P.P.; PUGLIESE, A. Comparison of effects of topical levobunolol to a combination of timololdorzolamide on intraocular pressure and pulse rate of healthy dogs. Vet. Res. Commun., v.33, p.205-207, 2009.

RIBEIRO, A.P., MARTINS, B., LAUS, J.L. Sindrome glaucomatosa em cães- Parte 2, Cienc. Rural., v.37, p.1828-1835, 2007. 
RIBEIRO, A.P.; JUNIOR, D.P.; CHAMPION, T. et al. Effects of topical levobunolol, or fixed combination of dorzolamide-timolol or association of dorzolamide-levobunolol on IOP, pupil size, and heart rate in healthy cats. Arq. Bras. Med. Vet. Zootec., v.60, p.1045-1052, 2008.

SMITH, L.N.; MILLER, P.E.; FELCHLE, L.M. Effects of topical administration of latanoprost, timolol, or a combination of latanoprost and timolol on intraocular pressure, pupil size, and heart rate in clinically normal dogs. Am. J. Vet. Res., v.71, p.1055-1061, 2010.

TILLEY, L.P. Interpretations of Q, R, S, T deflections. In TILLEY, L.P. Essentials of canine and feline electrocardiograph. Philadelphia: Lea and Fiber, 1992. p. 59-99.
WHEELER, L.A.; WOLDEMUSSIE, E. Alpha-2 adrenergic receptor agonists are neuroprotective in experimental models of glaucoma. Eur. J. Ophthalmol., v.11, p.30-35, 2001.

WILLIS, A.M. Ocular hypotensive drugs. Vet. Clin. N. Am.: Small Anim. Pract., v.34, p.755776, 2004.

WILKIE, D.A.; LATIMER, C.A. Effects of topical administration of timolol maleate on intraocular pressure and pupil size in dogs. Am. J. Vet. Res., v.52, p.432-435, 1991. 